\title{
Port-hinterland transport and logistics: emerging trends and frontier research
}

\author{
Behzad Behdani ${ }^{1} \cdot$ Bart Wiegmans ${ }^{2}$ - Violeta Roso ${ }^{3} \cdot$ Hercules Haralambides $^{4,5,6}$
}

(c) Springer Nature Limited 2019

\section{Introduction}

Cargo carried by liner shipping has come to be known as general cargo. ${ }^{1} \mathrm{Up}$ to the beginning of the 1960s, such cargo was transported, in various forms of unitization (packaging), such as pallets, slings, boxes, barrels and crates, by relatively small ships, known as general cargo ships, cargo freighters, multipurpose ships, twindeckers or multi-deckers. Cargo handling was a very labour-intensive process and ships were known to spend most of their time in port, waiting to berth, load or discharge. Congestion was a chronic problem in most ports, raising the cost of transport and hindering the growth of trade. Equally importantly, such delays in ports made trade movements erratic and unpredictable, obliging manufacturers, wholesalers and retailers to keep large stock. As a result, warehousing and carrying (capital) costs were adding up to the cost of transport, making final goods more expensive and, again, hindering international trade and economic development ${ }^{2}$ (Haralambides 2019).

This situation started to change in the 1960s with the introduction of the 'container' and containerization in the trade between the United States and Europe and,

\footnotetext{
1 This introduction leans heavily on Haralambides (2017, 2019).

${ }^{2}$ Cases have also been known where inefficient ports were welcomed (if not deliberately pursued) by governments, as an effective tariff and barrier to foreign imports.
}

Behzad Behdani

behzad.behdani@wur.nl

1 Operations Research and Logistics, Wageningen University and Research, Hollandseweg 1, 6706 KN Wageningen, The Netherlands

2 Department of Transport and Planning, Delft University of Technology, Delft, The Netherlands

3 Division of Service Management and Logistics, Chalmers University of Technology, Gothenburg, Sweden

4 Dalian Maritime University, Dalian, China

5 Texas A\&M University, College Station, USA

6 Erasmus University Rotterdam, Burg. Oudlaan 50, 3062 PA Rotterdam, The Netherlands 
subsequently, in the rest of the world. Containerization is often described as a revolution in transport. The innovation entailed in the concept of containerization is credited to Malcolm Mclean, an American trucker who thought of separating the tractor from the trailer part of his trucks, standardizing (unitizing) the latter (trailer) so as to be able to be transported with its contents intact by various transport means, handled at ports by standardized cargohandling equipment (quay cranes), and stacked uniformly one on top of the other, both on ships and at terminals. This was the start of intermodality, as well as of mega-ships and mega-ports, inland terminals, distribution centers (dry ports) and global logistics, by and large (Van Klink and van Den Berg 1998; McCalla 1999).

However, in spite of the sustained growth of port throughput worldwide, as well as of the substantial infrastructure investments of ports and their efforts to reform and modernize, hinterland transport-representing $60 \%$ of the costs of the global maritime supply chain (Beresford et al. 2012) — has not kept pace; productivity in the maritime leg of the supply chain has not been followed by productivity in its hinterland part, apart from the introduction of double-stack trains in the US in the 1980s (DeBoer 1992), or the adoption of the dry port concept in the 2000s (Roso et al. 2009). Moreover, the gigantism in container shipping ${ }^{3}$ is straining port infrastructure and cargohandling capacity, causing significant diseconomies of scale, which propagate throughout the supply chain, given that increases in port throughput generate almost proportional increases in hinterland flows, and functional seaport hinterland access is essential for the efficiency of the whole intermodal transportation chain. For many seaports, the weakest link in their transportation chains is hinterland access, due to congested roads and inadequate or non-existent rail connections, causing delays and increases in transport costs. The Transport Research Board (1993), as early as the 1990s, identified those infrastructure, land use, environmental and institutional impediments that reduce the efficiency of hinterland transport. To add to this, the quality of hinterland transport and inland access of ports depend on the behaviour of a large number of stakeholders involved in the seaport-transport system (de Langen and Chouly 2004; Paixão and Bernard Marlow 2003).

A reversal of trends can recently be seen. From the earlier days when ports were obliged to move downstream to find space, ports now look back at their hinterlands to find the additional space they require. Inland intermodal terminals (or dry ports) are thus mushrooming, connected to seaports by rail, road or inland waterways (Haralambides and Gujar 2011, 2012). As such, inland intermodal terminals are usually developed close to railway and motorway junctions to facilitate the transfer of containers between modes of transport, favoring, to the extent possible, the more environmentally friendly transport modes, such as rail and inland waterways (Rodrigue et al. 2016; Haralambides 2020).

A digression might be in order here. Despite various policies proposing and encouraging an increasing use of rail and intermodal solutions, especially in the European Union, the modal share of rail transport has been decreasing, mostly

\footnotetext{
3 At the time of writing, the biggest containership was the MSC Gulsun, capable of carrying up to 23,756 twenty-foot equivalent units (TEU).
} 


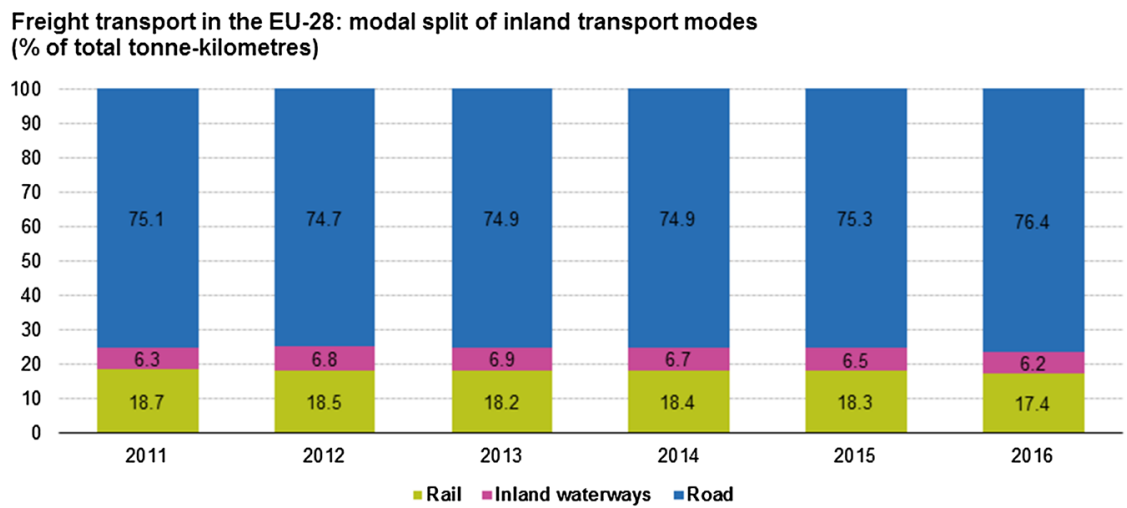

Note: EU-28 includes rail transport estimates for Belgium and Croatia and does not include road freight transport for Malta (negligible). Figures may not add up to $100 \%$ due to rounding.

Source: Eurostat (online data code: tran_hv_frmod)

\section{eurostat?}

Fig. 1 Freight Transport in the EU-28: modal split of inland transport modes (EEA 2009)

due to the removal of trade barriers and the liberalization of markets, which have resulted in an increased market share of road transport, representing $76.4 \%$ of inland freight transport in 2016 (EEA 2009) (Fig. 1). In the European Union, a change in the geographic orientation of trade and economic activity from the west to the east has also contributed to this situation, since the new markets are not well connected by rail, so therefore road prevails due to its flexibility (EEA 2009).

Containerization and intermodality have extended the hinterland of seaports and redefined seaport competition in a way that seaports now have to strive for a position in intermodal corridors (Notteboom 1997, 2006; Haralambides 2019).

In all cases, the role of the Port Authority (PA) - the autonomous body which manages the seaport-is crucial. PAs are assuming an increasingly enterprising role as 'stakeholder managers', extending their 'gates' to the hinterland, as far out as possible, to widen their catchment areas. To do this, the 'smart port authority 4.0' needs to smooth out supply chain bottlenecks among ships, terminals, customs authorities, and hinterland transport, storage and distribution. In its supply chain manager role, the seaport of today understands that it is now supply chains, not ports, that compete for custom (Haralambides 2020). Together with intra-port efficiency, therefore, the focus of port management is now also drawn to hinterland access via more active involvement in innovative logistics. Often, the objective of such efforts entails a shift of container flows from road to Intermodal Freight Transport (IFT) networks (both rail and inland waterways).

Such a role for PAs requires modern management practices and the transformation of the PA from a government dependency to an entity operating under increasingly commercial terms. Often, 'stakeholder management' is an extremely frustrating exercise in view of conflicting interests, particularly when such 'stakeholders' sit in the governing or supervising boards of port authorities. 


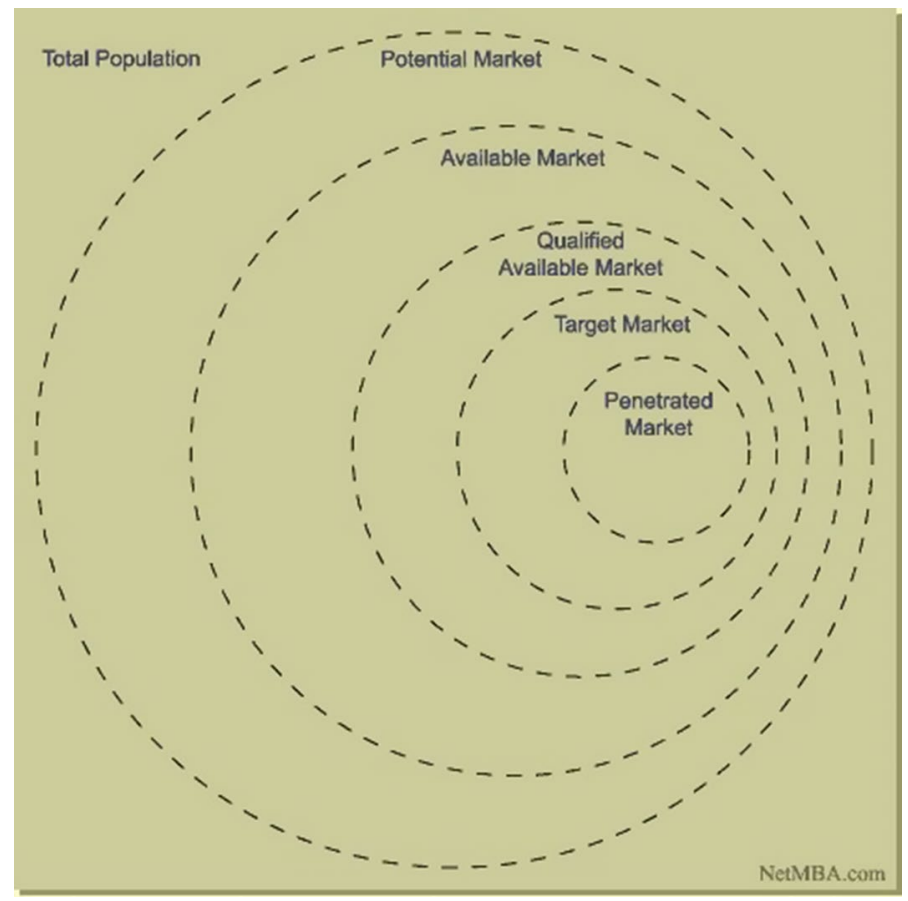

Fig. 2 Market definition. Source NetMBA.com

A port's hinterland is no longer static but dynamic. Thirty years ago, when port traffic was captive, one's students could easily calculate the optimum size of a port, based on the country's trade, population and growth data. Today, with expanding hinterlands and competition among ports, researchers would have to take a guess (i.e., forecast). The problem, however, is that someone will have to pay for this guess and this can no longer be the taxpayer. Rather, it has to be one whose role is to assume risk and be rewarded or punished for it; i.e. the private sector (Haralambides 2019).

From a competition economics and law point of view, the concept of 'hinterland', which is of interest, is expressed by the relevant geographic market (Haralambides 2017). A market has a geographical attribute which is of relevance in determining concentration and competition. For instance, the market of the city where the port is located is fairly captive. But as the port tries to extend its hinterland towards the region, the country or the continent, the market becomes just a potentially targetable market, with more players and thus more competition (Fig. 2). To give another example: The Shanghai-Rotterdam port-to-port market may be highly concentrated, with just a handful of carriers offering services, but if one were to consider that, actually, the market is the door-to-door importation of bicycles made in Wuhan, China to Paris, France, then the market is highly competitive with many players offering services, using not only those two ports but many others, at both ends of the trade. Simply put, if the market is 
Table 1 Overview of article searching terms

\begin{tabular}{lc}
\hline Key term & $\begin{array}{l}\text { Number of } \\
\text { articles found }\end{array}$ \\
\hline intermodal & 88 \\
hinterland & 72 \\
"intermodal freight transport" & 12 \\
"inland shipping" & 2 \\
"inland waterways" & 8 \\
"rail transport" & 5 \\
"road transport" & 9 \\
Total & 196
\end{tabular}

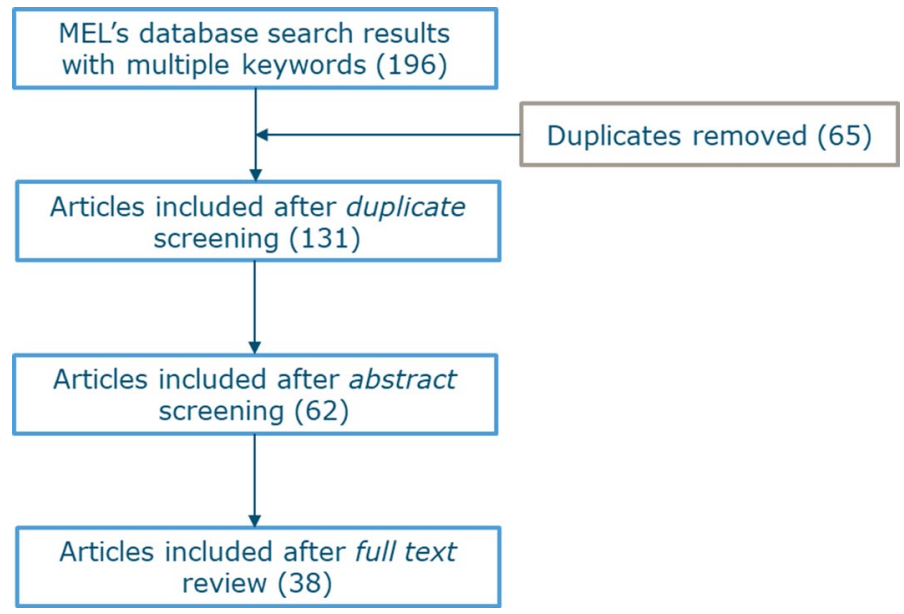

Fig. 3 Approach for paper selection

port-to-port, it could indeed be concentrated; if however the market is door-todoor, including a miscellany of add-on logistics services, it could well be considered as not concentrated at all (Haralambides 2017).

\section{The contribution of MEL to port-hinterland logistics and intermodal transport}

This section presents an overview of papers published in MEL on port-hinterland transportation. For this review, a structured and systematic approach in four phases was carried out. In the first phase, a pool of relevant papers was extracted from the MEL database in Scopus. The search was performed primarily using the more generic terms of "intermodal", "hinterland", and "intermodal freight transport" in the title, abstract, and keywords of published papers. The search was further extended with more specific key terms such as "inland shipping", "inland 


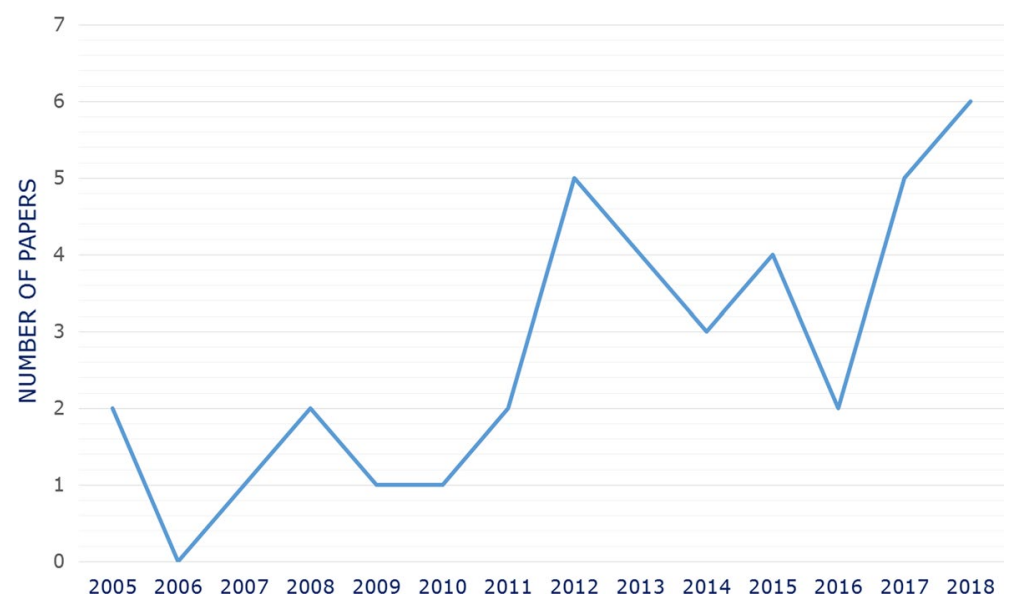

Fig. 4 Distribution of MEL articles on port-hinterland logistics and intermodal freight transport over time

waterways", "rail transport", and "road transport". The search was limited to those articles published by the end of 2018. The number of articles with each search term is shown in Table 1.

Our search resulted in 196 articles (Fig. 3). In the second phase, articles were screened to identify duplicates. This narrowed the results to 131 . These articles were reviewed in two phases to find the relevant ones. Firstly, the abstracts were reviewed, filtering 62 articles for the second phase, in which the articles were read in full, narrowing the list to 38 relevant articles. Those were the articles that either discuss only port-hinterland and intermodal freight transport, or articles in which a considerable part focuses on these topics. Papers with a focus on terminal operations, which only marginallydiscuss hinterland transport, or papers on port competitiveness where land transport or hinterland accessibility are just two among several factors were excluded from our analysis.

As Fig. 4 shows, the number of MEL articles on port-hinterland logistics and intermodal freight transport has been increasing steadily from 2005 to 2018. Selected papers were categorised into three groups, based on their main research area:

(i) Economic studies, focusing primarily on market mechanisms, market efficiency, as well as demand or cost analysis;

(ii) Operational studies, addressing the logistics and operational processes in hinterland transport;

(iii) Organizational/regulatory studies, focused on 'stakeholder management' and the relationship between stakeholders, as well as on analysing the regulatory and policy interventions. This category also includes the innovative business models for port-hinterland logistics. 


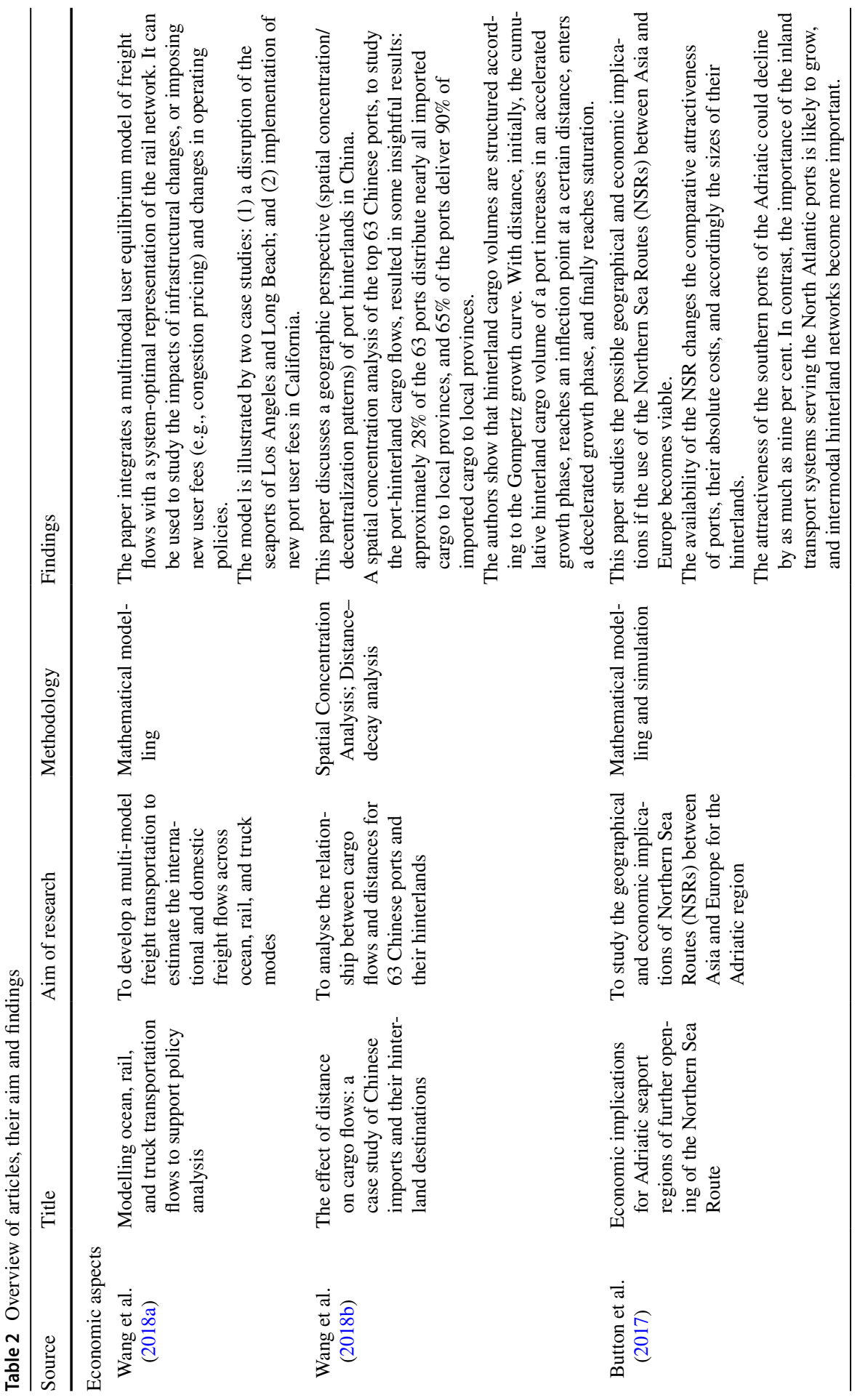




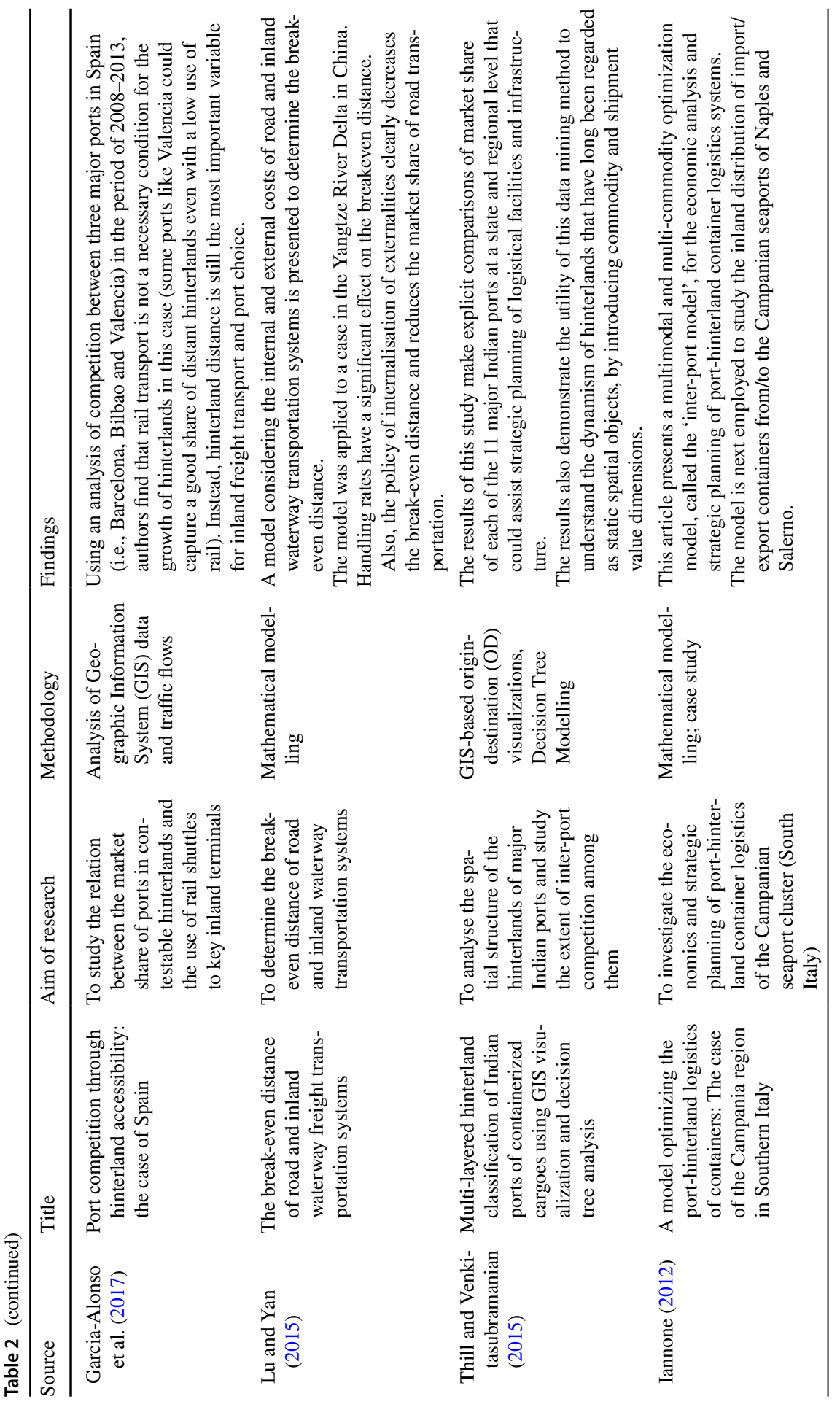

䞡 


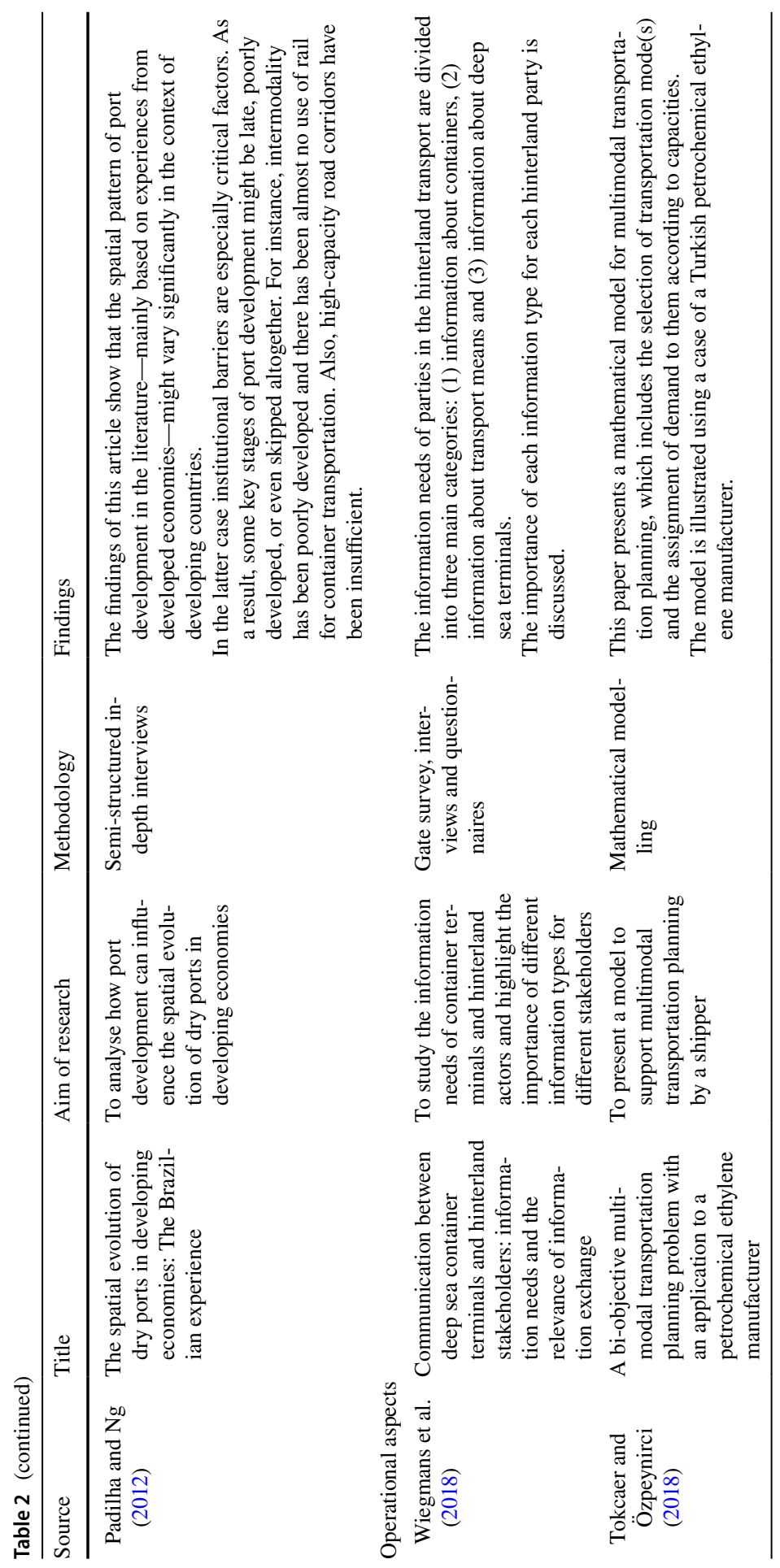




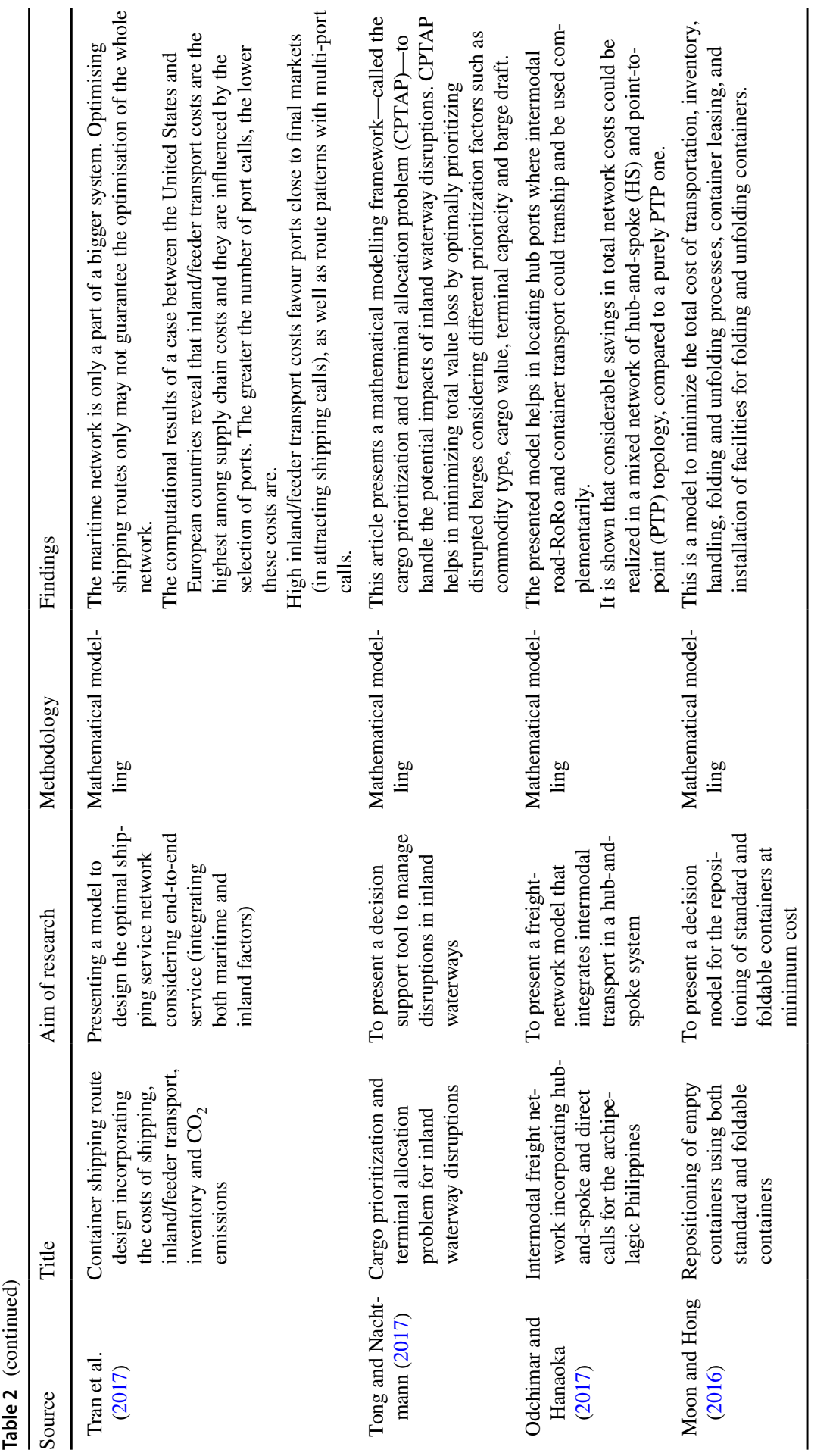

我造 


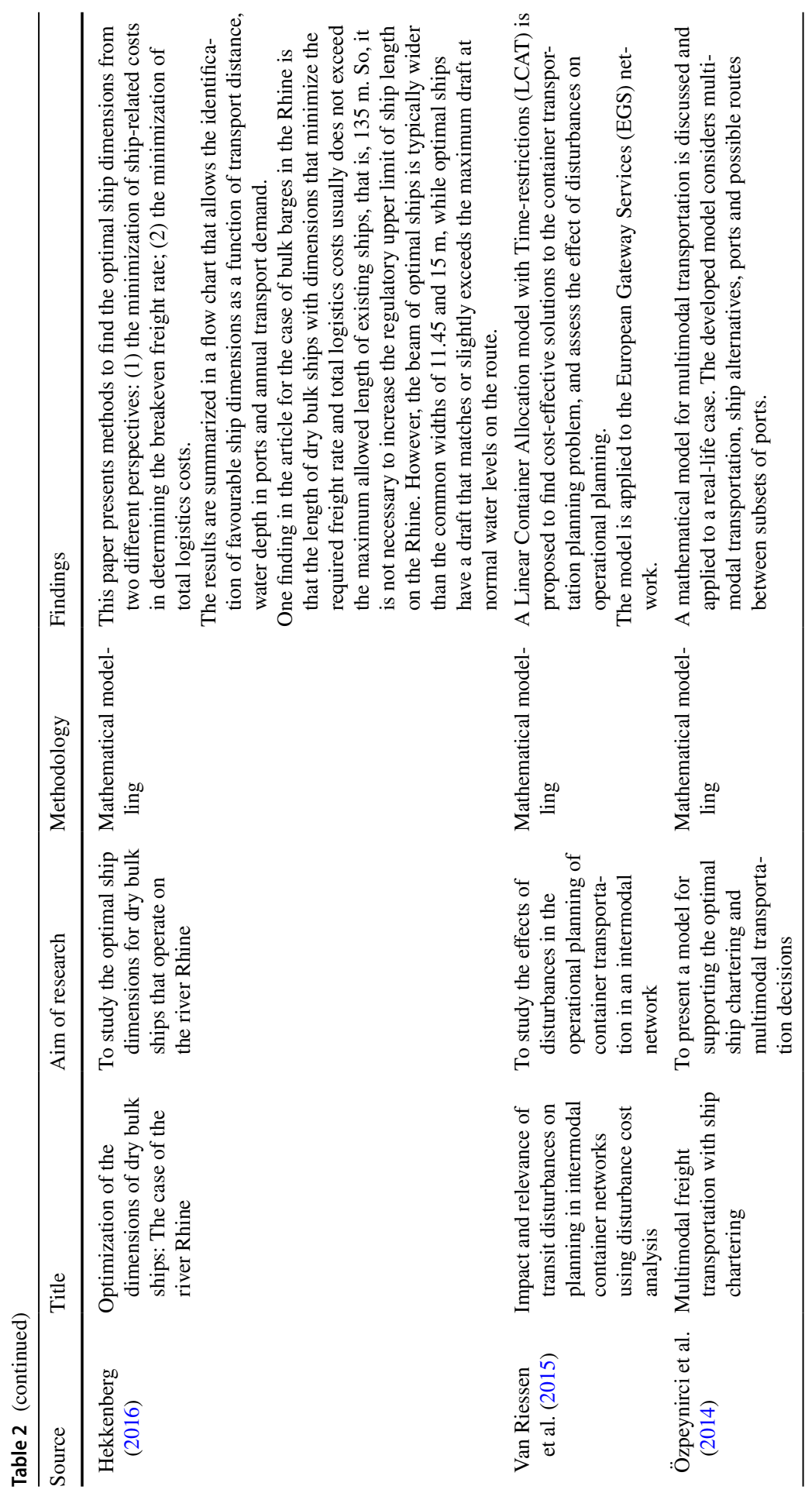




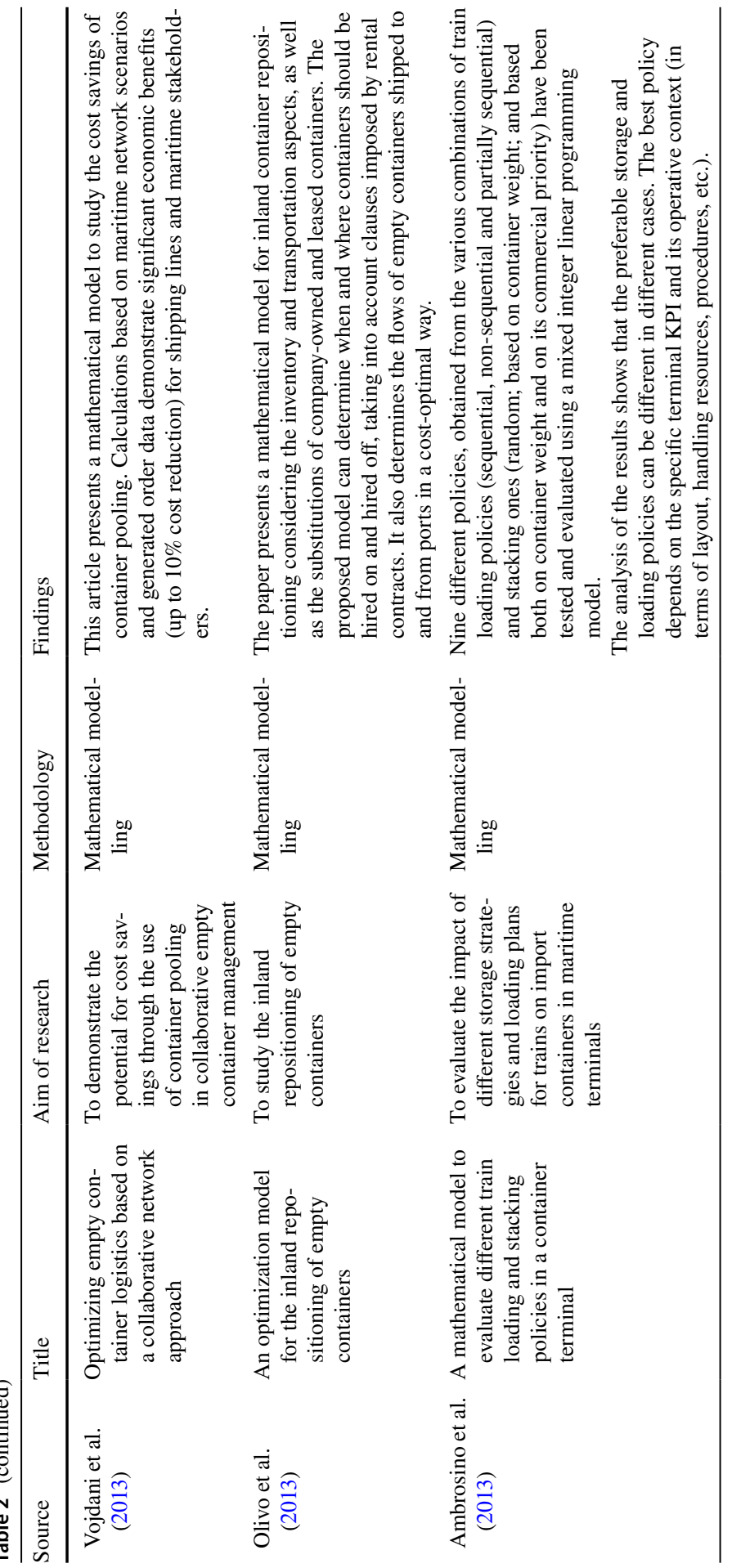

称。 


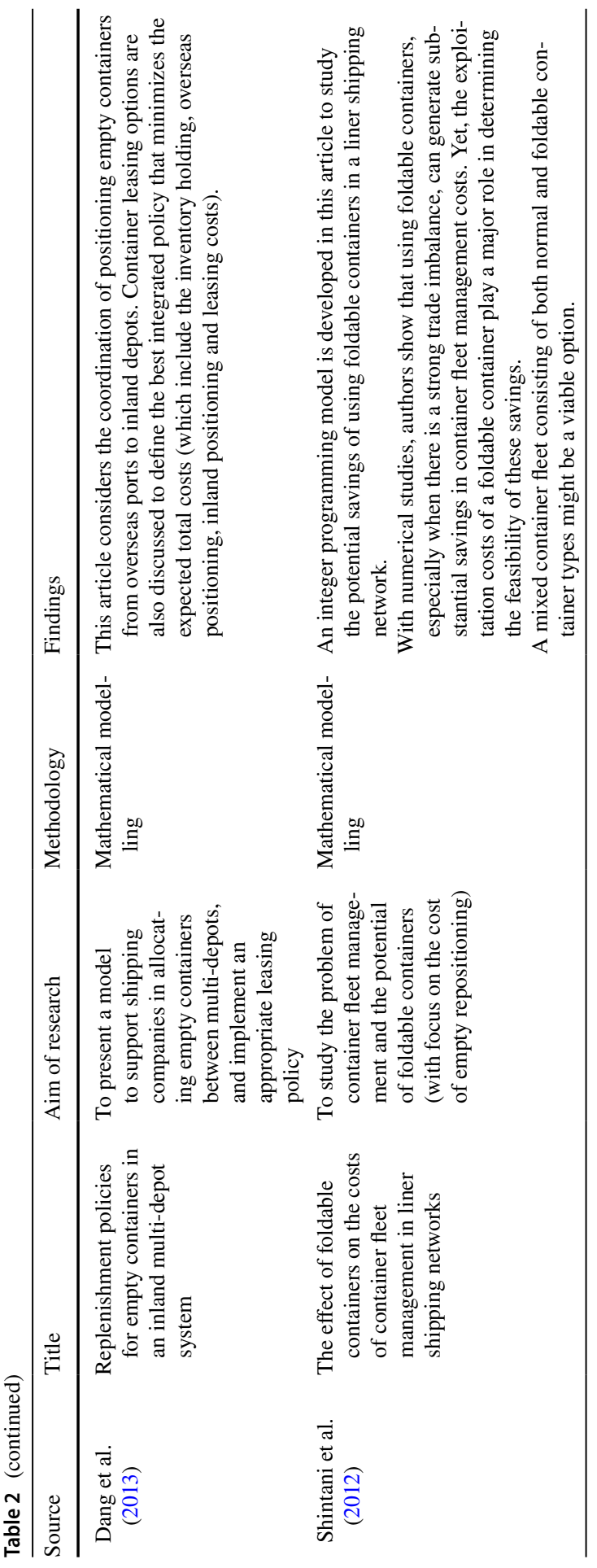




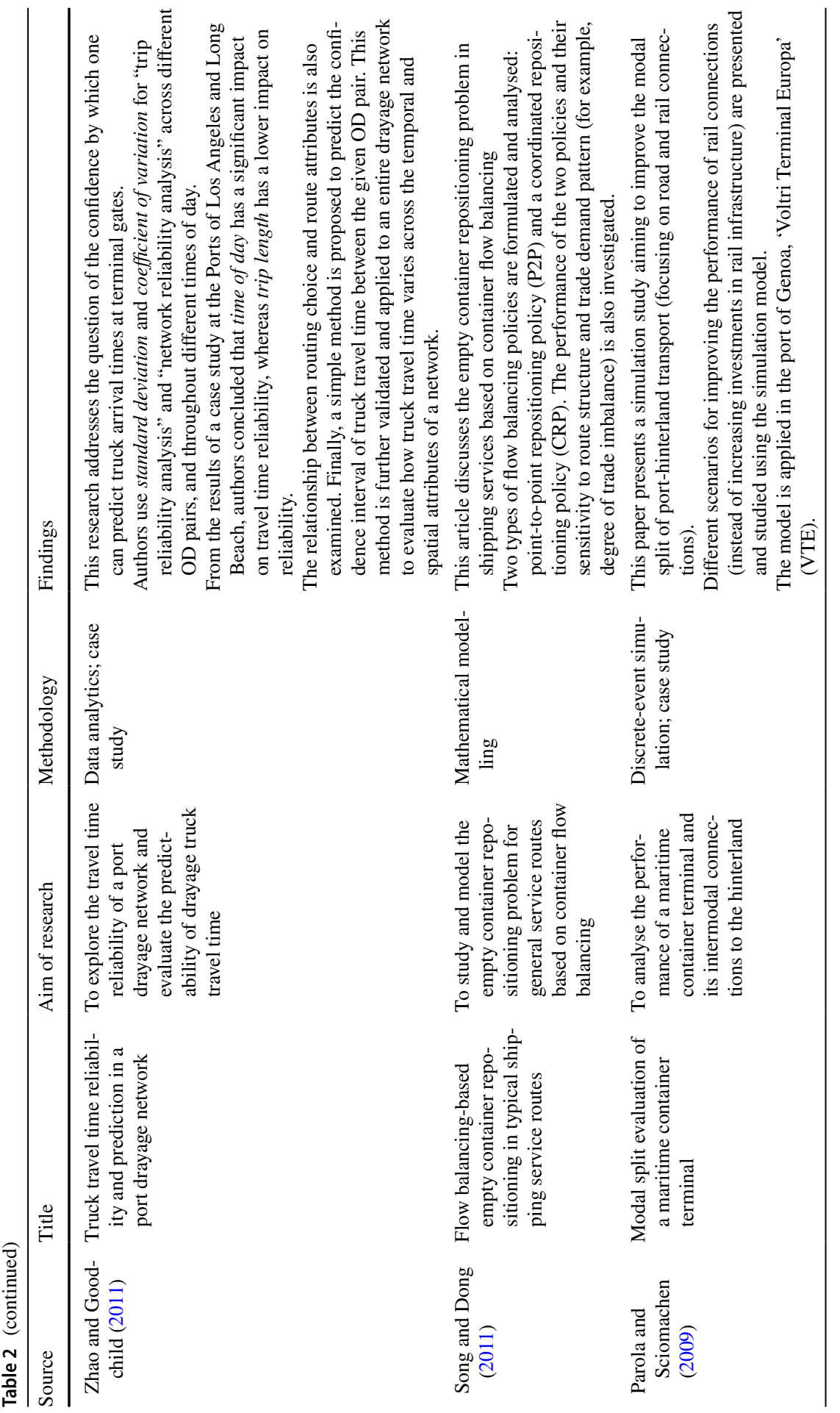

我 


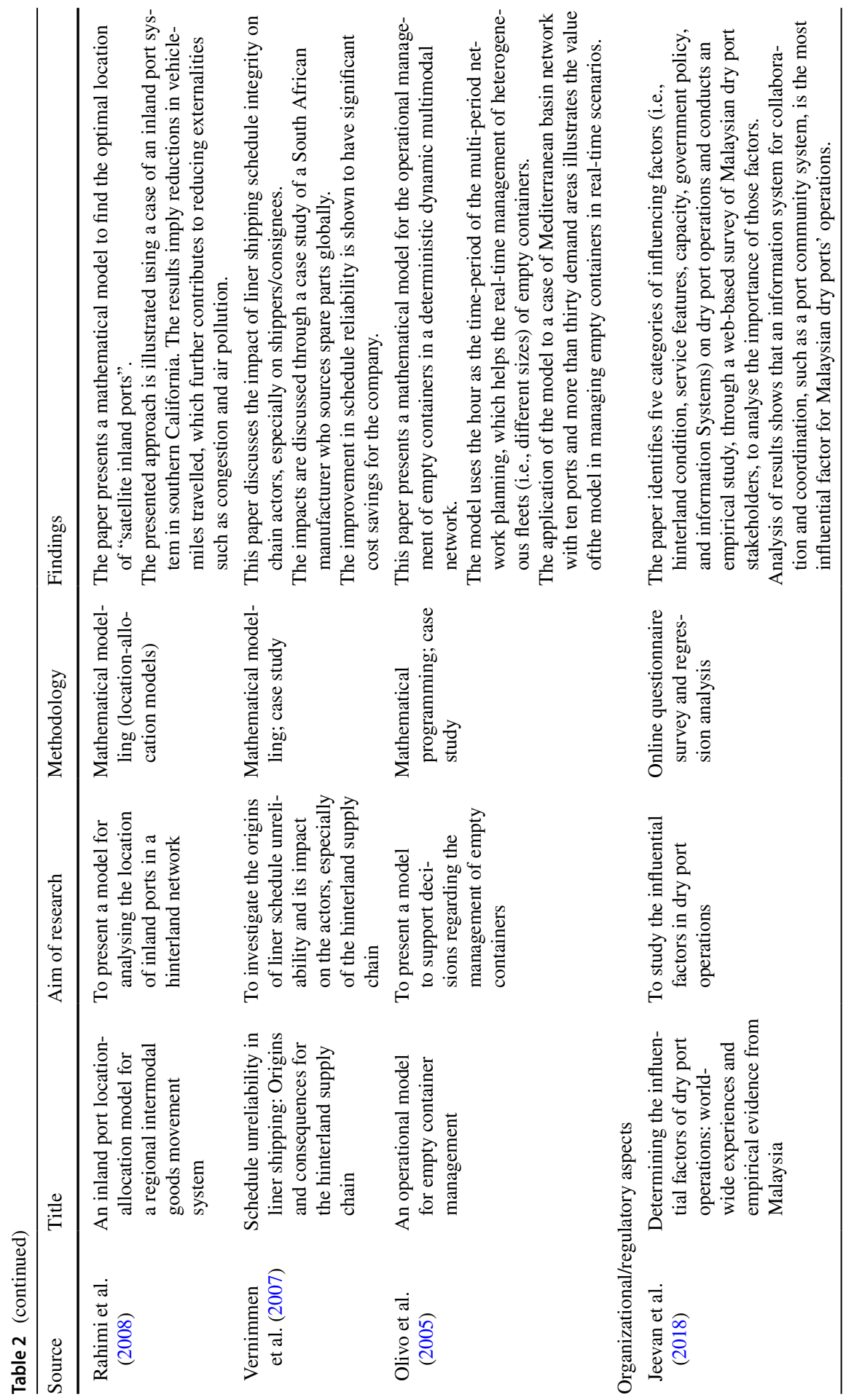




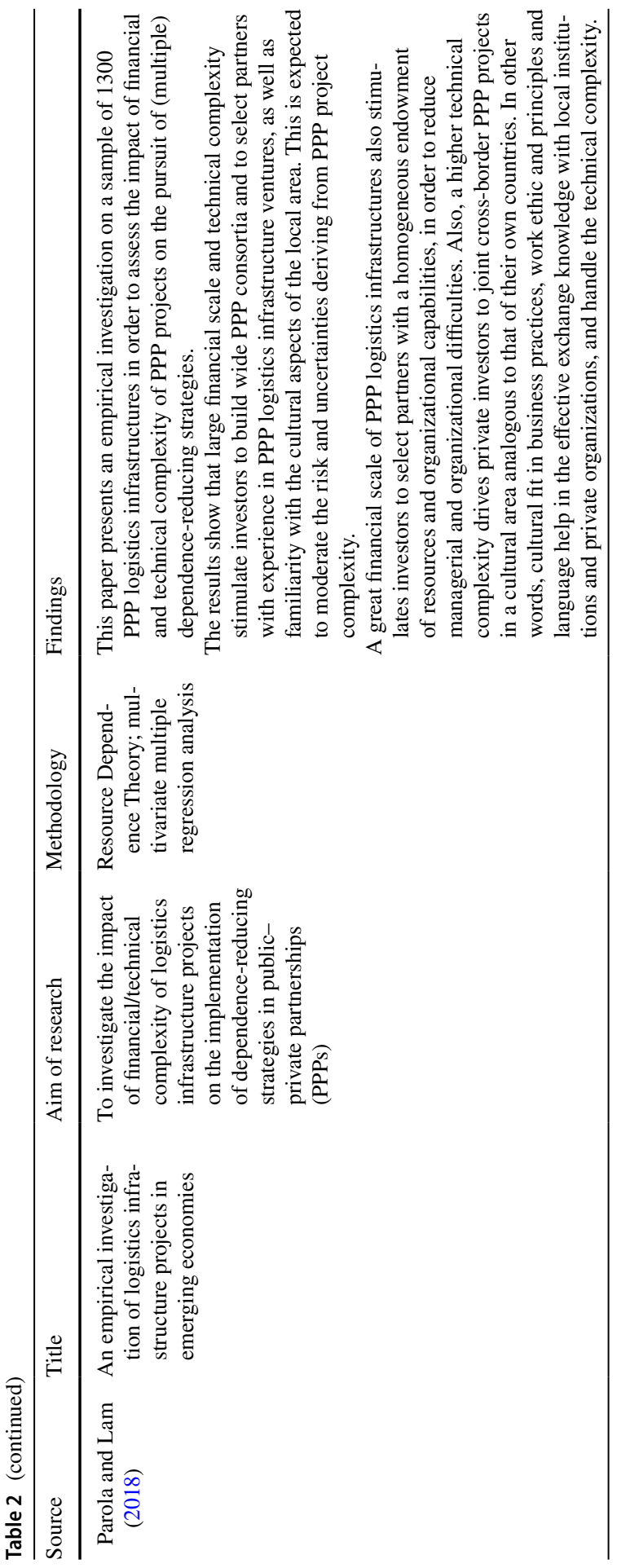

站 


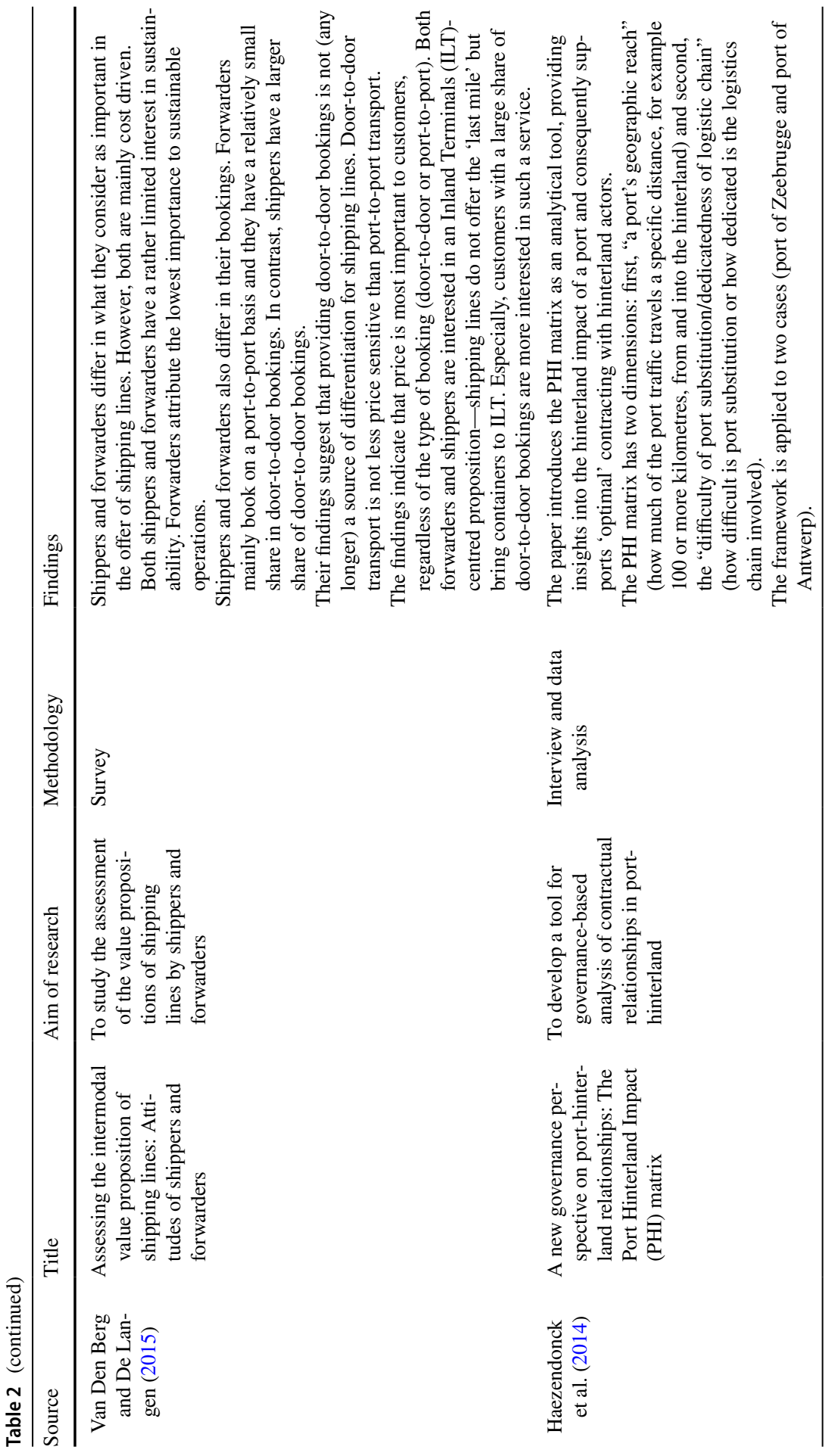




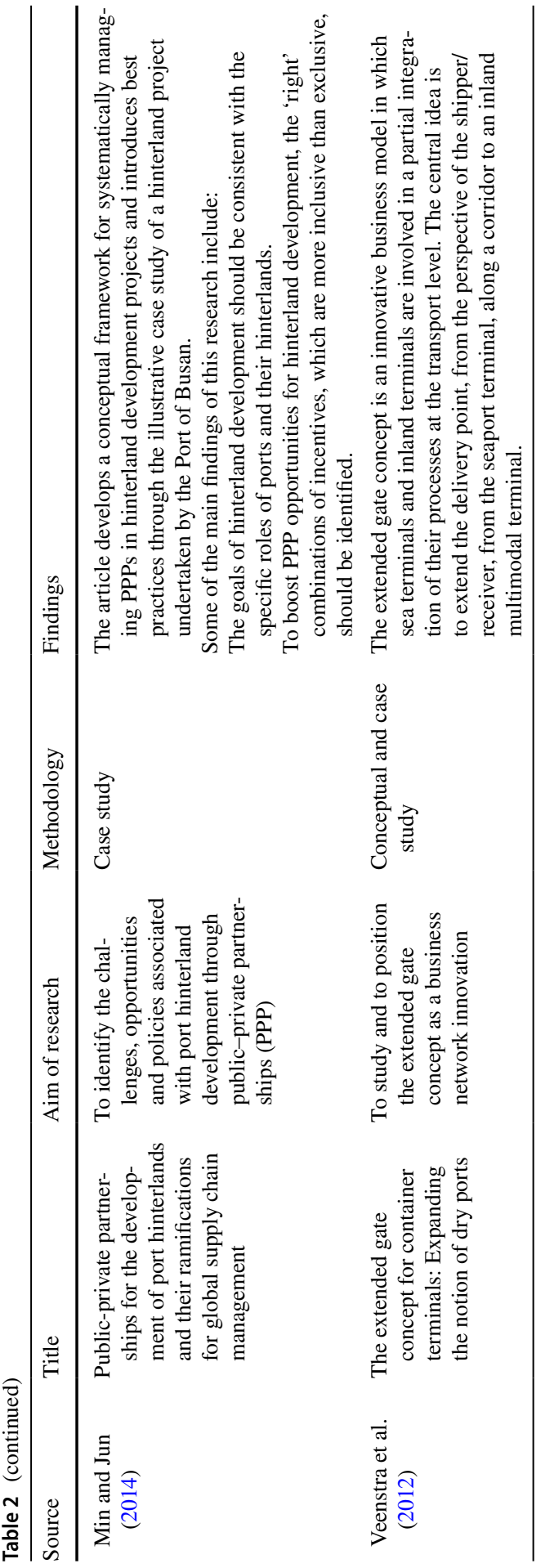

称。 


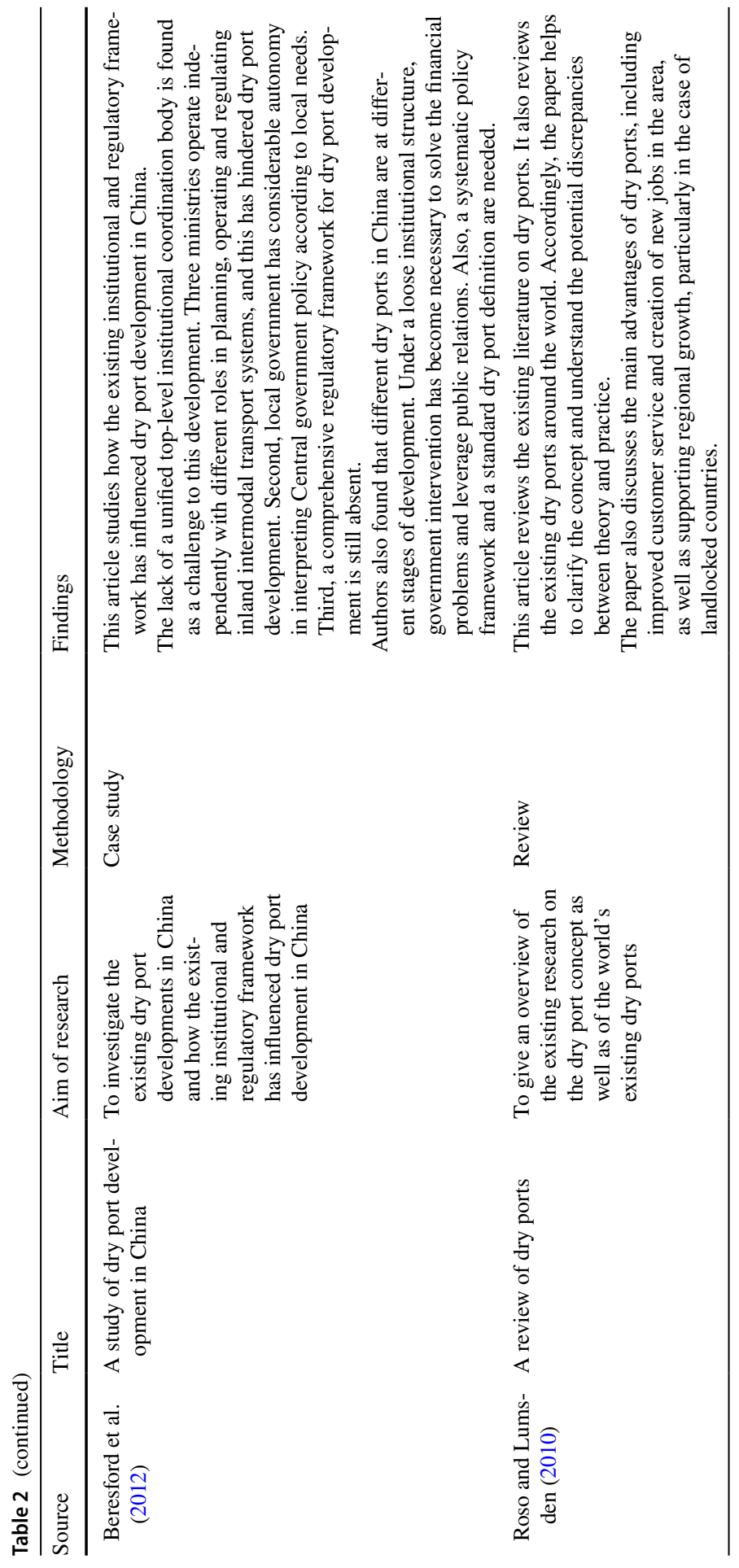




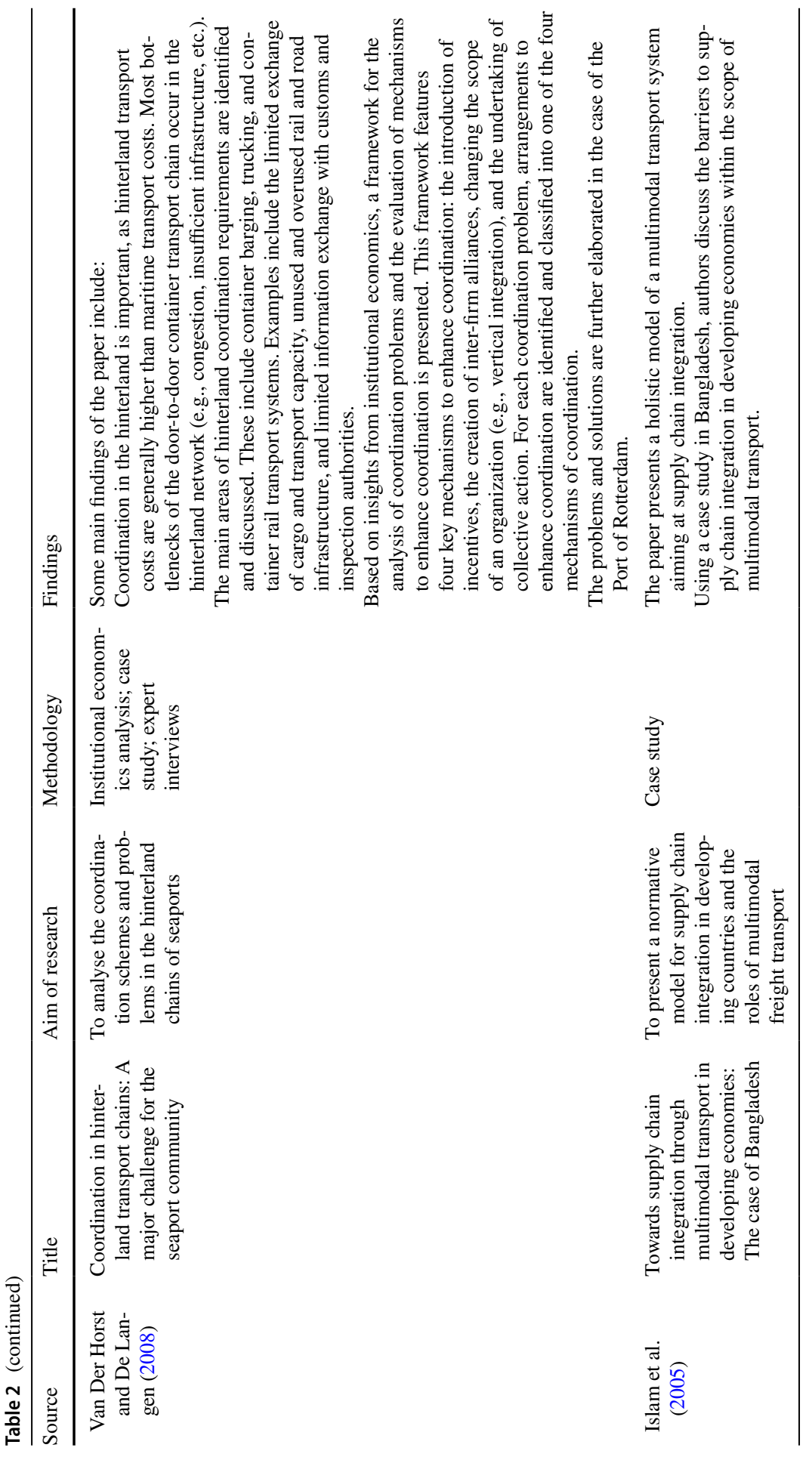

我 
The details of the aim and contribution of the articles in these three groups are presented in Table 2. Although the categorization in Table 2 is not intended to be definitive (since some articles may discuss more than one topic), the main topic has been used in the categorization of Table 2. Thus, the table provides a general overview of problems addressed by different researchers and their key findings. For operational and economic aspects, the dominant methodology is mathematical modelling. For organizational aspects, the survey and case study methods are the most widely used methods. It is interesting to observe that as many as 85 percent of the papers discuss a case - as the main research method, or to illustrate their models or frameworks - which demonstrates the highly practical relevance of the findings in these articles.

\section{Contents of this special issue}

This special issue brings together five papers representing cutting edge research currently pursued in the area of port-hinterland transportation. In the first paper (The geography of container port choice: modelling impacts of changes in hinterland variables on port choice), Mueller, Wiegmans and van Duin study the position of port hinterlands in the modelling of port choice. Their model discusses how containerized imports could be affected by changes in the hinterland strategies of ports and hinterland corridors, as well as by changes in inland port operations. They further model the impact of fuel prices on port hinterlands. They find that although a rise in fuel prices might reduce road transport, this is influencing the competitive position of ports at a European level.

The role of the hinterland in port choice is also studied by Caballe-Valls, de Langen, Garcia-Alonso, and Vallejo-Pinto (Understanding port choice determinants and port hinterlands; findings from an empirical analysis of Spain). Based on detailed Spanish customs data, the authors show that intermodal connectivity is a determinant of the market share of a port in a certain hinterland region. Additionally, the authors show that, in the case of Spanish ports, there are no clear 'boundaries' between the hinterlands of different ports, which thus have market shares in 'contestable hinterlands'. Finally, it is also shown that hinterlands may actually differ, depending on overseas destination.

In their paper, The impact of foldable containers on cost savings in empty container relocation by trucks in the hinterland of seaports, Shintani, Konings, Nishimura, and Imai focus on the empty container relocation problem in hinterland transport. Empty container re-positioning is an important operational issue in maritime logistics. Foldable containers may present a potential solution, since when an empty container is folded, it needs less space on transport means. The authors present a model to address the integrated problem of truck routing and empty container relocation by using foldable containers.

In Involvement of port authorities in inland logistics markets: the cases of Rotterdam, Le Havre, and Marseille, Magnan and van der Horst discuss an important organizational and governance aspect of port-hinterland logistics, i.e., the role of port authorities in the development of inland logistics markets. The authors discuss 
the typology of different roles, actions and instruments that port authorities can adopt within inland logistics markets. They further study three cases: Port of Rotterdam (the Netherlands), Le Havre (France) and Marseille-Fos (France). The case studies rely on in-depth interviews with port authorities and public administrations and illustrate the different paths followed by the three port authorities. In Rotterdam, there has been a shift from a conservator to a facilitator model and later to an entrepreneurial role. However, the port authority has recently withdrawn from its entrepreneurial role, presently functioning more like a facilitator. The port authorities of Le Havre and Marseille-Fos mix the conservator and facilitator models. ${ }^{4}$

In the last paper of this issue, a framework for modelling and analysing coordination challenges in hinterland transport systems, Gumuskaya, van Jaarsveld, Dijkman, Grefen, and Veenstra focus on an important organizational issue in port-hinterland logistics. They present a framework for exploring the coordination challenges in hinterland transport within three layers of transportation processes: contracting, planning and physical processes. The framework can help in formalizing coordination models and in gaining insights into the dynamics of coordination challenges. Their effort is illustrated through a case study of barge congestion in the Port of Rotterdam.

\section{Further research and agenda for action}

Based on the contributions in this special issue and on our own research overview, we have, subjectively of course, identified the following areas for further research on maritime transport, ports and hinterlands: coping with increasing volumes; synchromodality; sustainability of intermodal freight transport; the value of information in intermodal transport; formalization of relations among stakeholders; intermodal freight transport policy making; and cooperation versus control.

Gigantism in container shipping (Haralambides 2019) creates challenges both for seaports and their hinterland. In a number of cases, capacities of inland modes and inland terminals have not kept pace with the growth in ocean transportation. These shortages manifest themselves in congestion and also in sustainability issues (UNCTAD 2017). In terms of further research, this leads to capacity optimization efforts, performance modelling, and also research into system breakthroughs in order to reduce emissions and the environmental footprint of the transport system.

\footnotetext{
${ }_{4}$ In terms of position and activities, a port authority can take different functional roles (De Langen 2006; Verhoeven 2010). The landlord function aims at maintenance and development of the port estate, as well as the provision of infrastructure. The regulator function is generally about controlling and policing functions (for example in terms of safety and security of ships and cargo, or port sustainability and labor regulations). The operator function aims at providing port services, including the physical transfer of cargo between sea and land or the provision of technical services (such as fleet maintenance). A port authority can also function as community manager or cluster manager by facilitating interactions, e.g., by investing in IT communication platforms. Finally, entrepreneurial function aims at fostering innovation by direct investment or supporting innovative companies that provide the logistics services at the port or its hinterland.
} 
Another important issue for further research is synchromodality. Synchromodality looks into the (integrated) combination of hinterland transport modes (rail, IWT, road). The concept of synchromodality especially attempts to integrate the planning of the different modes, and it therefore calls for the development of planning models optimizing hinterland transport (Behdani et al. 2016). Also, from an organizational point of view, we need some new and innovative contract types for synchromodality, both between customers and transport operators and between transport operators themselves, if the latter aim to share capacity. From an economics point of view, synchromodal pricing and the modelling of synchromodal demand are some of the areas calling for further research.

Sustainability efforts of existing intermodal modes is another research challenge. Road freight transport quickly improves its environmental performance while intermodal freight transport clearly lags behind. Efforts are needed in the development of new and cleaner technologies for intermodal freight transport. The effects of such technologies need to be studied in a way that should encourage the shift to a more sustainable freight transport system.

Efficiency improvements are often attributed to the increasing use of information in freight transport chains (e.g. Blockchain). We feel that further research is needed into the role, effects and impacts of the increasing use of information for, so far, the actual business cases of such efficiency improvements are missing.

An interesting issue for further research is the formalization of relations between stakeholders (e.g. between maritime terminals and transport operators) in freight transport chains. A notable example is the handling of barges by deep-sea terminals. The latter provide a service to the barge operator, being paid, however, by a freight forwarder or a logistics service provider. Because of this indirect relation (which is not formalized by a contact between barge and terminal operator), barges are often given lower priority compared to ocean shipping. More organizational research is needed into efficient solutions that can change this type of relationships, making them more formal. Modelling might be able to measure the efficiency impacts on freight transport chains.

Revisiting intermodal transport policy is another practical as well as academic area. In the last 30 years, this policy has had no effect and the market share of road transport increased from 75.1 in 2011 to $76.4 \%$ in 2016 (EEA 2009). Further research is needed into policy options that are able to increase the market share of intermodal freight transport versus single-mode road transport.

\section{References}

Ambrosino, D., C. Caballini, and S. Siri. 2013. A mathematical model to evaluate different train loading and stacking policies in a container terminal. Maritime Economics \& Logistics 15 (3): 292-308.

Behdani, B., Y. Fan, B. Wiegmans, and R. Zuidwijk. 2016. Multimodal schedule design for synchromodal freight transport systems. European Journal of Transport and Infrastructure Research 16 (3): 424-444.

Beresford, A., S. Pettit, Q. Xu, and S. Williams. 2012. A study of dry port development in China. Maritime Economics \& Logistics 14 (1): 73-98.

Button, K., T. Kramberger, T. Vizinger, and M. Intihar. 2017. Economic implications for Adriatic seaport regions of further opening of the Northern Sea Route. Maritime Economics \& Logistics 19 (1): 52-67. 
Dang, Q.V., I.E. Nielsen, and W.Y. Yun. 2013. Replenishment policies for empty containers in an inland multi-depot system. Maritime Economics \& Logistics 15 (1): 120-149.

De Langen, P.W. 2006. Stakeholders, conflicting interests and governance in port clusters. In Devolution, port governance and port performance Research in transportation economics, ed. M.R. Brooks and K. Cullinane, vol. 17, 457-477.

De Langen, P.W., and A. Chouly. 2004. Hinterland access regimes in seaports. European Journal of Transport and Infrastructure Research 4 (4): 361-380.

DeBoer, D.J. 1992. Piggyback and containers: A history of rail intermodal on America's steel highway. San Marino, CA: Golden West Books.

EEA. 2009. Transport at a crossroads. TERM 2008: Indicators tracking transport and environment in the European Union. ISSN 1725-9177.

Garcia-Alonso, L., J. Monios, and J.Á. Vallejo-Pinto. 2017. Port competition through hinterland accessibility: the case of Spain. Maritime Economics \& Logistics 21: 258-277.

Haralambides, H.E. 2017. Globalization, public sector reform, and the role of ports in international supply chains. Maritime Economics and Logistics 19 (1): 1-51.

Haralambides, H.E. 2019. Gigantism in container shipping, ports and global logistics: A time-lapse into the future. Maritime Economics and Logistics 21 (1): 1-60.

Haralambides, H.E. 2020. Containerization and the port industry. In International encyclopaedia of transportation, ed. Roger Vickerman. Elsevier (forthcoming).

Haralambides, H.E., and G. Gujar. 2011. The Indian dry ports sector: Pricing policies and opportunities for public-private partnerships. Research in Transportation Economics 33 (2011): 51-58. https://doi. org/10.1016/j.retrec.2011.08.006.

Haralambides, H.E., and G. Gujar. 2012. On balancing supply chain efficiency and environmental impacts: An eco-DEA model applied to the dry port sector of India. Maritime Economics and Logistics 14 (1): $122-137$.

Haezendonck, E., M. Dooms, and A. Verbeke. 2014. A new governance perspective on port-hinterland relationships: The Port Hinterland Impact (PHI) matrix. Maritime Economics \& Logistics 16 (3): 229-249.

Hekkenberg, R. 2016. Optimization of the dimensions of dry bulk ships: The case of the river Rhine. Maritime Economics \& Logistics 18 (2): 211-229.

Iannone, F. 2012. A model optimizing the port-hinterland logistics of containers: The case of the Campania region in Southern Italy. Maritime Economics \& Logistics 14 (1): 33-72.

Islam, D.M.Z., J. Dinwoodie, and M. Roe. 2005. Towards supply chain integration through multimodal transport in developing economies: The case of Bangladesh. Maritime Economics \& Logistics 7 (4): 382-399.

Jeevan, J., S.L. Chen, and S. Cahoon. 2018. Determining the influential factors of dry port operations: Worldwide experiences and empirical evidence from Malaysia. Maritime Economics \& Logistics 20 (3): 476-494.

Lu, C., and X. Yan. 2015. The break-even distance of road and inland waterway freight transportation systems. Maritime Economics \& Logistics 17 (2): 246-263.

McCalla, R.J. 1999. Global change, local pain: Intermodal seaport terminals and their service areas. Journal of Transport Geography 7 (4): 247-254.

Min, H., and C.Y. Jun. 2014. Public-private partnerships for the development of port hinterlands and their ramifications for global supply chain management. Maritime Economics \& Logistics 16 (3): 250-275.

Moon, I., and H. Hong. 2016. Repositioning of empty containers using both standard and foldable containers. Maritime Economics \& Logistics 18 (1): 61-77.

Notteboom, T.E. 1997. Concentration and load centre development in the European container port system. Journal of Transport Geography 5 (2): 99-115.

Notteboom, T. 2006. Strategic challenges to container ports in a changing market environment. Research in Transportation Economics 17: 29-52.

Odchimar, A., and S. Hanaoka. 2017. Intermodal freight network incorporating hub-and-spoke and direct calls for the archipelagic Philippines. Maritime Economics \& Logistics 19 (2): 352-378.

Olivo, A., M. Di Francesco, and P. Zuddas. 2013. An optimization model for the inland repositioning of empty containers. Maritime Economics \& Logistics 15 (3): 309-331.

Olivo, A., P. Zuddas, M. Di Francesco, and A. Manca. 2005. An operational model for empty container management. Maritime Economics \& Logistics 7 (3): 199-222.

Özpeynirci, Ö., K. Üçer, and T. Tabaklar. 2014. Multimodal freight transportation with ship chartering. Maritime Economics \& Logistics 16 (2): 188-206.

Padilha, F., and A.K. Ng. 2012. The spatial evolution of dry ports in developing economies: The Brazilian experience. Maritime Economics \& Logistics 14 (1): 99-121. 
Paixão, A.C., and P. Bernard Marlow. 2003. Fourth generation ports-A question of agility? International Journal of Physical Distribution \& Logistics Management 33 (4): 355-376.

Parola, F., and J.S.L. Lam. 2018. An empirical investigation of logistics infrastructure projects in emerging economies. Maritime Economics \& Logistics 20 (1): 48-71.

Parola, F., and A. Sciomachen. 2009. Modal split evaluation of a maritime container terminal. Maritime Economics \& Logistics 11 (1): 77-97.

Rahimi, M., A. Asef-Vaziri, and R. Harrison. 2008. An inland port location-allocation model for a regional intermodal goods movement system. Maritime Economics \& Logistics 10 (4): 362-379.

Rodrigue, J.P., C. Comtois, and B. Slack. 2016. The geography of transport systems. New York: Routledge.

Roso, V., and K. Lumsden. 2010. A review of dry ports. Maritime Economics \& Logistics 12 (2): 196-213.

Roso, V., J. Woxenius, and K. Lumsden. 2009. The dry port concept: Connecting container seaports with the hinterland. Journal of Transport Geography 17 (5): 338-345.

Shintani, K., R. Konings, and A. Imai. 2012. The effect of foldable containers on the costs of container fleet management in liner shipping networks. Maritime Economics \& Logistics 14 (4): 455-479.

Song, D.P., and J.X. Dong. 2011. Flow balancing-based empty container repositioning in typical shipping service routes. Maritime Economics \& Logistics 13 (1): 61-77.

Thill, J.C., and K. Venkitasubramanian. 2015. Multi-layered hinterland classification of Indian ports of containerized cargoes using GIS visualization and decision tree analysis. Maritime Economics \& Logistics 17 (3): 265-291.

Tokcaer, S., and Ö. Özpeynirci. 2018. A bi-objective multimodal transportation planning problem with an application to a petrochemical ethylene manufacturer. Maritime Economics \& Logistics 20 (1): 72-88.

Tong, J., and H. Nachtmann. 2017. Cargo prioritization and terminal allocation problem for inland waterway disruptions. Maritime Economics \& Logistics 19 (3): 403-427.

Tran, N.K., H.D. Haasis, and T. Buer. 2017. Container shipping route design incorporating the costs of shipping, inland/feeder transport, inventory and $\mathrm{CO}_{2}$ emission. Maritime Economics \& Logistics 19 (4): 667-694.

Transport Research Board (TRB). 1993. Landside Access to U.S. Ports, Special Report 238. Washington: National Academy Press.

UNCTAD. 2017. Review of maritime transportation. New York: United Nations Publication.

Van den Berg, R., and P.W. De Langen. 2015. Assessing the intermodal value proposition of shipping lines: Attitudes of shippers and forwarders. Maritime Economics \& Logistics 17 (1): 32-51.

Van Der Horst, M.R., and P.W. De Langen. 2008. Coordination in hinterland transport chains: A major challenge for the seaport community. Maritime Economics \& Logistics 10 (1-2): 108-129.

Van Klink, H.A., and G.C. van Den Berg. 1998. Gateways and intermodalism. Journal of Transport Geography 6 (1): 1-9.

Van Riessen, B., R.R. Negenborn, G. Lodewijks, and R. Dekker. 2015. Impact and relevance of transit disturbances on planning in intermodal container networks using disturbance cost analysis. Maritime Economics \& Logistics 17 (4): 440-463.

Veenstra, A., R. Zuidwijk, and E. Van Asperen. 2012. The extended gate concept for container terminals: Expanding the notion of dry ports. Maritime Economics \& Logistics 14 (1): 14-32.

Verhoeven, P. 2010. A review of port authority functions: Towards a renaissance? Maritime Policy \& Management 37 (3): 247-270.

Vernimmen, B., W. Dullaert, and S. Engelen. 2007. Schedule unreliability in liner shipping: Origins and consequences for the hinterland supply chain. Maritime Economics \& Logistics 9 (3): 193-213.

Vojdani, N., F. Lootz, and R. Rösner. 2013. Optimizing empty container logistics based on a collaborative network approach. Maritime Economics \& Logistics 15 (4): 467-493.

Wang, L., A. Goodchild, and Y. Wang. 2018a. The effect of distance on cargo flows: A case study of Chinese imports and their hinterland destinations. Maritime Economics \& Logistics 20 (3): 456-475.

Wang, H., L. Nozick, N. Xu, and J. Gearhart. 2018b. Modeling ocean, rail, and truck transportation flows to support policy analysis. Maritime Economics \& Logistics 20 (3): 327-357.

Wiegmans, B., I. Menger, B. Behdani, and B. van Arem. 2018. Communication between deep sea container terminals and hinterland stakeholders: Information needs and the relevance of information exchange. Maritime Economics \& Logistics 20 (4): 531-548.

Zhao, W., and A.V. Goodchild. 2011. Truck travel time reliability and prediction in a port drayage network. Maritime Economics \& Logistics 13 (4): 387-418.

Publisher's Note Springer Nature remains neutral with regard to jurisdictional claims in published maps and institutional affiliations. 